\title{
ANALISIS PERBANDINGAN PENURUNAN FONDASI DANGKAL DI TANAH GAMBUT DENGAN STABILISASI KAPUR DAN ABU SEKAM PADI
}

\author{
Aviva Stevani ${ }^{1}$, dan Chaidir Anwar Makarim ${ }^{2}$ \\ ${ }^{1}$ Program Studi Sarjana Teknik Sipil, Universitas Tarumanagara, Jl. Letjen S. Parman No.1 Jakarta \\ aviva.325170113@stu.untar.ac.id \\ ${ }^{2}$ Program Studi Sarjana Teknik Sipil, Universitas Tarumanagara, Jl. Letjen S. Parman No.1 Jakarta \\ Chaidir259@gmail.com
}

Masuk:11-01-2021, revisi:01-02-2021, diterima untuk diterbitkan: 11-02-2021

\begin{abstract}
The increase in housing needs is in line with the increase in the population. Residential buildings in Indonesia are only about 1-2 floors, which require shallow foundations to support. Land is one of the important aspects, where it supports the entire building that stands on it. One of the development constraints encountered in Kalimantan is the peat soil. The construction on peatland will cause problems such as low bearing capacity and large deformation, therefore it needs improvement before use. This study aims to find out the overview of shallow foundation settlement with a size of $2 m \times 2 m$ with a depth of $1 \mathrm{~m}$ in untreated soils with a thickness of $6 \mathrm{~m}$ and in stabilized peat soils. Stabilization used by $10 \%$ of the dry weight of the soil with a content of $30 \%$ lime $+70 \%$ ash husk rice. Calculation of the settlement in stabilized peat soil, there're 5 variations of stabilization thickness ranging from 2 $m-6 m$. Within 30 years, the total settlement of untreated peat soil by $1,25828 \mathrm{~m}$, as well as for stabilizing peat soils with a thickness of $2 \mathrm{~m}-6 \mathrm{~m}$ experienced a total settlement of 0,534587 m to 0,379714 m.
\end{abstract}

Keywords: peat soil; stabilization; shallow foundation; settlement

\begin{abstract}
ABSTRAK
Peningkatan kebutuhan rumah tinggal selaras dengan peningkatan jumlah penduduk. Pada umumnya bangunan rumah tinggal di Indonesia hanya berkisar 1- 2 lantai, dimana membutuhkan fondasi dangkal untuk menopang beban. Tanah merupakan salah satu aspek penting, dimana tanah menopang seluruh bangunan yang berdiri diatasnya. Salah satu kendala pembangunan yang ditemui di Kalimantan adalah lapisan tanah gambut. Pembangunan bangunan diatas tanah gambut akan menimbulkan masalah seperti daya dukung yang rendah serta penurunan yang besar, maka dari itu perlu perbaikan sebelum digunakan. Penelitian kali ini bertujuan untuk mengetahui sebuah gambaran mengenai penurunan fondasi dangkal dengan ukuran $2 \mathrm{~m}$ x $2 \mathrm{~m}$ dengan kedalaman 1 $\mathrm{m}$ pada tanah gambut asli (untreated soil) dengan ketebalan $6 \mathrm{~m}$ serta pada tanah gambut yang telah distabilisasi. Stabilisasi yang digunakan sebesar 10\% dari berat kering tanah dengan kadar 30\% kapur $+70 \%$ abu sekam padi. Perhitungan penurunan pada tanah gambut yang telah distabilisasi, ada 5 variasi ketebalan stabilisasi mulai dari 2 $\mathrm{m}-6 \mathrm{~m}$. Dalam jangka waktu 30 tahun, penurunan total tanah gambut asli sebesar 1,25828 m, serta untuk tanah gambut stabilisasi dengan ketebalan $2 \mathrm{~m}-6 \mathrm{~m}$ mengalami penurunan total sebesar 0,534587 m sampai 0,379714 $\mathrm{m}$.
\end{abstract}

Kata Kunci: gambut; stabilisasi; fondasi dangkal; penurunan.

\section{PENDAHULUAN}

Jakarta dianggap sudah tidak mampu lagi menopang segala kegiatan pemerintahan akibat keterbatasan lahan dan kepadatan penduduk serta kesenjangan ekonomi yang terjadi di pulau-pulau lain di Indonesia, khususnya di luar Pulau Jawa yang disebabkan oleh keberadaan pusat bisnis yang mendominasi di Pulau Jawa, maka Presiden Joko Widodo memutuskan untuk memindahkan Ibu Kota ke Kalimantan Timur. Dengan pindahnya ibu kota, pasti akan terjadi transmigrasi ke Kalimantan yang menyebabkan peningkatan jumlah penduduk. Hal tersebut mengakibatkan peningkatan kebutuhan sandang, pangan, dan terutama papan yaitu rumah tinggal. Pada umumnya konstruksi rumah tinggal di Indonesia hanya berkisar $1-2$ lantai, dimana pasti membutuhkan metode konstruksi fondasi dangkal. 
Dengan luas 21 juta ha, Indonesia dinobatkan sebagai salah satu negara dengan luas lahan gambut tropika terbesar di dunia yang terdistribusi di Sumatera (7,2 juta ha), Kalimantan (5,8 juta ha) dan Papua (8,0 juta ha) (Wibowo, 2009). Dimana Provinsi Kalimantan Tengah sendiri sudah mencakup 55\% atau sekitar 2,66 juta ha dari keseluruhan luas sebaran di Kalimantan dengan dominasi kedalaman $>400 \mathrm{~cm}$ (D4).

Tanah gambut dianggap tidak cocok untuk mendukung bangunan dikarenakan kadar air yang cukup tinggi yaitu berkisar 100-1.300\% dari berat kering (Mutalib et al., 1991) yang menyebabkan volume tanah (bulk density) menjadi rendah sehingga berpengaruh pada nilai daya tahan (bearing capacity) yang rendah. Tanah gambut memiliki sifat yang mengering tidak balik (irreversible drying), dimana apabila gambut yang mengering dengan kadar $<100 \%$ (berdasarkan berat), maka tidak bisa lagi menyerap air. Gambut yang kering ini akan memiliki sifat yang mirip dengan kayu kering dimana akan mudah terbawa aliran air serta mudah terbakar dalam keadaan kering (Widjaja,A, 1988). Serta penyusutan volume gambut apabila lahan didrainage yang mengakibatkan terjadi penurunan tanah (subsidence).

Untuk mengatasi masalah penurunan tanah yang timbul akibat pembebanan di atas tanah gambut dengan rata-rata kedalaman 4 - 8m diperlukan metode perbaikan tanah yang tepat untuk meningkatkan daya dukung tanah dan mengurangi penurunan akibat pembebanan. Salah satu metode perbaikan tanah yang dapat dilakukan adalah dengan stabilisasi menggunakan bahan kimia (chemical stabilizer) seperti kapur, semen dsb. Diharapkan setelah di stabilisasi, penurunan akibat beban menjadi berkurang jika dibandingkan dengan tanah asli (untreated soil).

Beberapa Batasan masalah yang digunakan dalam penelitian ini yaitu: fondasi dangkal yang digunakan berbentuk bujur sangkar dengan ukuran $200 \mathrm{~cm}$ x $200 \mathrm{~cm}$, dnegan kedalaman $100 \mathrm{~cm}$, pembebanan yang akan dipakai adalah beban rata-rata untuk rumah tinggal 2 lantai pada satu fondasi, yaitu beban vertical sebesar 20,9 kN dan beban momen sebesar $8,96 \mathrm{kNm}$, lapisan tanah dasar yang digunakan untuk desain yaitu tanah gambut dengan ketebalan $6 \mathrm{~m}$, stabilisasi tanah gambut dengan menggunakan kapur (30\%) + abu sekam padi (70 \%) sebanyak 10\% dari berat kering tanah, pada perhitungan tanah gambut dengan stabilisasi, ada 5 variasi kedalaman stabilisasi yang digunakan yaitu: $2 \mathrm{~m}, 3 \mathrm{~m}, 4 \mathrm{~m}, 5 \mathrm{~m}$, dan $6 \mathrm{~m}$, perhitungan penurunan hanya sebatas pada ketebalan lahan gambut, yaitu $6 \mathrm{~m}$.

Rumusan masalah yang akan dibahas dalam penelitian ini: bagaimana perbandingan hasil data lab tanah gambut asli dengan tanah gambut yang sudah distabilisasi, berapa total penurunan yang terjadi pada tanah gambut asli dan pada tanah gambut yang distabilisasi, berapa persentase perbedaan penurunan yang terjadi pada tanah gambut asli dan tanah gambut yang sudah distabilisasi.

Beberapa tujuan yang akan dibahas pada penelitian ini: mengetahui perbandingan hasil data lab tanah gambut asli dengan tanah gambut yang sudah distabilisasi, mengetahui total penurunan yang terjadi pada tanah gambut asli dan pada tanah gambut yang telah distabilisasi, mengetahui besar persentase perbedaan penurunan yang terjadi pada tanah gambut asli dan tanah gambut yang sudah di stabilisasi.

\section{Tanah Gambut}

Tanah gambut merupakan tanah dari hasil akumulasi timbunan bahan-bahan organik dari vegetasi tumbuhan yang mengalami pelapukan secara alami dalam jangka waktu yang panjang. Menurut Nurida et al (2011), tanah gambut memiliki kadar $\mathrm{pH}$ serta kesuburan yang rendah akibat proses dekomposisi yang belum terjadi secara sempurna yang diakibatkan karena gambut yang cenderung selalu jenuh. Menurut Noor (2014), sifat dan pembentukan dari tanah gambut dipengaruhi oleh topografi, iklim, jenis lapisan di bahwa gambut serta jenis bahan organik pembentuknya.

Gambut merupakan tipe tanah yang mengandung kadar organik yang tinggi. Menurut Pd T-06-2004-B, kadar organik tanah gambut $>75 \%$. Sebagian tanah gambut di Indonesia merupakan tanah gambut oligotrofik dna mesotrofik. Kandungan mineral dan ketebalan lapisan tanah mempengaruhi tingkat kesuburan tanah gambut. Menurut ASTM D4427-92, tanah gambut diklasifikasikan berdasarkan tingkat adsorbs (kemampuan menampung air), kadar abu serta tingkat kematangan tanah.

\section{Sifat Fisik Tanah Gambut}

Untuk menentukan perlakuan yang tepat ketika mendirikan sebuah konstruksi diatas tanah gambut, berikut beberapa sifat fisik tanah gambut yang penting diketahui.

\section{Kadar Air}

Kadar air merupakan besarnya kandungan air yang ada di dalam tanah. Menurut Mutalib et al (1991), tanah gambut memiliki kadar air yang cukup tinggi, yaitu berkisar antara $100-1.300 \%$ dari berat keringnya yang diakibatkan tingginya daya adsorbsi yang dimiliki oleh tanah gambut. 


\section{Berat Jenis (specific gravity)}

Berat jenis adalah rasio perbandingan antara berat jenis zat pada partikel tanah dengan berat unit air pada volume yang sama pada suhu $40^{\circ} \mathrm{C}$. Menurut Hardiyatmo (2002), acuan untuk berat jenis tanah gambut dapat dilihat pada Tabel 1.

Tabel 1. Berat Jenis (specific gravity)

\begin{tabular}{cc}
\hline Jenis Tanah & Spesific Gravity \\
\hline Kerikil & $2,65-2,68$ \\
Pasir & $2,65-2,68$ \\
Lanau tak organik & $2,65-2,68$ \\
Lempung organik & $2,58-2,65$ \\
Lempung tak organik & $2,68-2,75$ \\
Humus & 1,37 \\
Gambut & $1,20-1,25$ \\
\hline (Sumber: Hardiyatmo, 2002)
\end{tabular}

\section{Angka Pori}

Pada umumnya, tanah gambut memiliki angka pori berkisar antara 5-15, dimana angka pori semakin besar pada gambut yang berserat disbanding tanah gambut granular yang memiliki angka pori berkisar 2. Angka pori yang cukup besar menyebabkan berat volume tanah menjadi sangat kecil.

\section{Berat Isi (bulk density)}

Menurut Nugroho dan Widodo (2001), berat isi tanah gambut di Indonesia berkisar 0,07- 0,27 g/cm3. Berat isi tanah gambut di Kalimantan Tengah berdasarkan kematanganya: gambut fibrik $(0,07-0,09 \mathrm{~g} / \mathrm{cm} 3)$, gambut hemik $(0,11-0,15 \mathrm{~g} / \mathrm{cm} 3)$, dan gambut saprik $(0,19-0,22 \mathrm{~g} / \mathrm{cm} 3)$ (Salamapak, 1999). Tanah dengan nilai berat isi yang terlalu rendah akan menyebabkan tanah memiliki daya tanah yang rendah.

\section{Porositas}

Menurut Nugroho dan Widodo (2001), porositas tanah gambut umumnya relatif tinggi berkisar 83,62-95,31\%. Porositas tanah berkorelasi secara positif terhadap kedalaman dan tingkat kematangan gambut. Semakin tebal gambut, maka semakin tidak matang gambut, semakin tidak matang gambut, maka semakin tinggi porositasnya. Porositas tanah gambut dapat menurun seiring dengan pengeringan tanah secara terus-menerus. Menurut Vicky (2020), gambut sapric mengalami penurunan yang paling tinggi, diikuti gambut hemik dan yang terendah yaitu gambut fibrik.

\section{Susut (shrinkage)}

Proses kehilangan air serta dekomposisi bahan orgnik yang berjalan dapat menyebabkan penyusutan. Menurut Agus dan Subiksa (2008), penyusutan pada tanh gambut dapat mencapai 50\% dari volume awal serta gambut tidak dapat menyerap air kembali setelah menyusut.

\section{Kapasitas Simpan Air}

Menurut Andriesse (1988), kapasitas simpan air dari tanah gambut berkisar $289-1.057 \%$ tergantung pada tingkat kematangan tanah. Kelembaban gambut (peat moisture) di daerah Sumatera dan Kalimantan antara $301-705 \%$ (Atmawidjaja, 1988). Hasil penelitian Andriessen (1988) dan Stevenson (1994) menunjukkan bahwa gambut memiliki kemampuan mengikat air sampai 20x berkat keringnya.

\section{Sifat Kimia Tanah Gambut}

Tanah gambut mengandung zat hara yang rendah dan berbagai jenis asam organik yang bersifat racun bagi tanaman, sehingga secara alamiah tanah gambut memiliki tingkat kesuburan yang rendah. Sifat kimia tanah gambut dipengaruhi oleh karakterisik dari asam organik, dimana asam tersebut merupakan bagian dari tanah aktif yang menetukan kemampuan tanah gambut untuk mempertahankan unsur hara.

\section{Tingkat Keasaman}

Menurut ASTM D2976, tanah gambut diklasifikasikan sebagai berikut:

- $\quad$ Highly acidic $(\mathrm{pH}<4,5)$ 
- Moderately acidic ( $\mathrm{pH}$ antara 4,5 - 5,5)

- Slightly acidic (pH am antara 5,5-7)

- $\operatorname{Basic}(\mathrm{pH} \geq 7)$

\section{Kadar Abu}

Menurut ASTM D 2974-87, pengujian kadar abu pda tanah gambut dilakukan dengan memasukkan tanah gambut ke dalam oven dengan suhu $440^{\circ}-750^{\circ} \mathrm{C}$ sampai sampel tanah berubah menjadi abu. Sistem kalsifikasi gambut berdasarkan kadar abu terlampir pada Gambar 1.

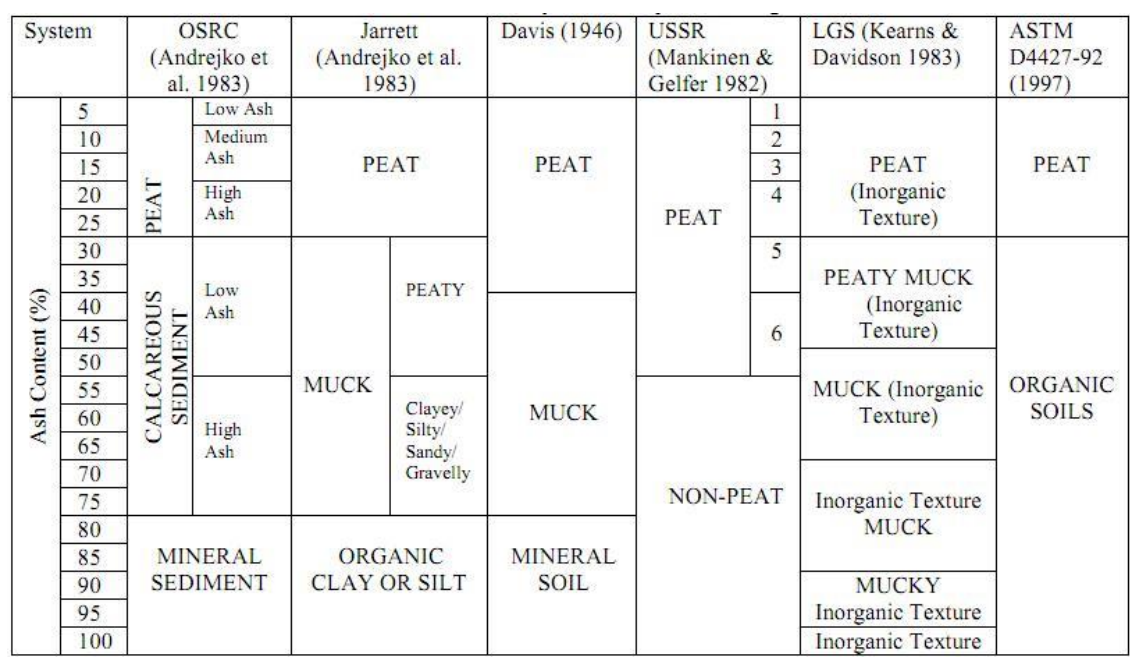

Gambar 1. Sistem Klasifikasi Gambut Berdasarkan Kadar Abu (Sumber: ASTM-4427)

\section{Stabilisasi Tanah}

Stabilisasi tanah merupakan upaya perbaikan tanah untuk memenuhi spesifikasi desain ketika bertemu dengan tanah bermasalah. Menurut Hardiyatmo (2010), stabilisasi tanah diukur dari perubahan karakteristik teknis tanah seperti, daya dukung, kompresibilitas, kemudahan pengerjaan, potensi pengembangan serta sensitivitas terhadap perubahan kadar air.

Sifat tanah gambut yang kurang menguntungkan bagi pembangunan konstruksi di atasnya memerlukan suatu perbaikan (soil improvement) untuk meningkatkan daya dukungnya (bearing capacity) sebelum digunakan. Metode stabilisasi yang digunakan pada tanah gambut adalah metode stablisiasi kimiawi, yaitu mencampurkan bahan lain ke dalam tanah gambut untuk memperbaiki sifat-sifat tanah gambut tersebut. Penggunaan kapur dna abu sekam padi untuk tanah gambut sudah diteliti oleh Faisal dan Noor (2014), dimana persentase optimum didapat pada campuran stabilisasi 30\% kapur dan 70\% abu sekam padi dengan kadar bahan stabilisasi 10\% dari tanah gambut.

Banyak kajian yang menunjukkan bahwa penambahan abu sekam padi dengan bahan tambah lain seperti kapur, semen, dsb dapat meningkatkan sifat-sifat fisik dan geoteknik tanah. Abu sekam padi (rice husk ash) merupakan salah satu abahan pozzolan dengan kandungan silika yang tinggi sehingga cukup baik untuk konstruksi.

\section{Penurunan}

Penurunan akibat penambahan beban di atas permukaan tanah disebabkan adanya deformasi tanah akibat keluarnya air atau udara dari dalam pori-pori tanah. Pada umunya, penurunan (settlement) pada tanah akibat pembebanan dikelompokkan menjadi dua, yaitu penurunan elastis (elastic settlement) dan penurunan konsolidasi (consolidation settlement). Dengan menjumlahkan kedua jenis penurunan tersebut, maka akan dapat diperkirakan besar penurunan total $(\mathrm{St})$;

$$
\mathrm{S}=\mathrm{S}_{e}+\left(\mathrm{S}_{\mathrm{c}}+\mathrm{S}_{\mathrm{s}}\right)
$$

dengan $\mathrm{S}=$ penurunan total, $\mathrm{S}_{e}=$ penurunan elastis, $\mathrm{S}_{\mathrm{c}}=$ penurunan primer dan $\mathrm{S}_{\mathrm{s}}=$ penurunan sekunder. 


\section{Penurunan Elastis}

Penurunan elastis merupakan penurunan akibat dari deformasi elastis tanah kering, basah, dan jenuh air tanpa adanya perubahan kadar air. Besarnya penurunan bergantung pada fleksibilitas serta ketentuan dari tipe fondasi serta material yang digunakan. Perhitungan penurunan elastis sebagai berikut:

$$
\begin{gathered}
S_{e}=q_{o}\left(\alpha B^{\prime}\right) \frac{1-\mu_{s}^{2}}{E_{s}} I_{s} I_{f} \\
I_{s}=F_{1} \frac{1-2 \mu_{s}}{1-\mu_{s}} F_{2} \\
F_{1}=\frac{1}{\pi}\left(A_{0}+A_{1}\right) \\
F_{2}=\frac{n^{\prime}}{2 \pi} \tan ^{-1} A_{2} \\
A_{0}=m^{\prime} \ln \frac{\left(1+\sqrt{m^{\prime 2}+1}\right) \sqrt{m^{\prime 2}+n^{\prime 2}}}{m^{\prime}\left(1+\sqrt{m^{\prime 2}+n^{\prime 2}+1}\right)} \\
A_{1}=\ln \frac{\left(m^{\prime}+\sqrt{m^{\prime 2}+1}\right) \sqrt{1+n^{\prime 2}}}{m^{\prime}+\sqrt{m^{\prime 2}+n^{\prime 2}+1}} \\
A_{2}=\frac{m^{\prime}}{n^{\prime} \sqrt{m^{\prime 2}+n^{\prime 2}+1}} \\
E_{s}=K_{c} x C_{u}
\end{gathered}
$$

Untuk perhitungan di sisi fondasi:

$$
\begin{aligned}
\alpha & =1 \\
m^{\prime} & =\frac{L}{B} \\
n^{\prime} & =\frac{H}{B}
\end{aligned}
$$

Untuk perhitungan di tengah fondasi:

$$
\begin{gathered}
\alpha=4 \\
m^{\prime}=\frac{L}{B} \\
n^{\prime}=\frac{H}{\left(\frac{B}{2}\right)}
\end{gathered}
$$

dengan $\mathrm{S}_{e}=$ penurunan elastis, $q_{o}=$ tekanan bersih yang diterima fondasi, $\mu_{s}=$ rasio Poisson tanah, $E_{s}=$ modulus rata-rata tanah dibawah fondasi, yang diukur dari $\mathrm{z}=0$ hingga $\mathrm{z}=5 \mathrm{~B}, I_{s}=$ factor bentuk, $I_{f}=$ factor kedalaman dari Tabel 2.3 dan Tabel 2.4, $\Delta z=$ nilai terkecil antara $\mathrm{H}$ dan $5 \mathrm{~B}, E_{s(i)}=$ modulus elastisitas tanah pada keadalaman $\Delta z, C_{u}=$ kuat geser undrained, $F=$ factor keamanan terhadap keruntuhan geser dan $\alpha=$ factor yang tergantung pada lokasi penurunan fondasi.

Penentuan nilai poisson tanah berdasarkan jenis tanah dapat dilihat lebih lanjut pada Tabel 2. 
Analisis Perbandingan Penurunan Fondasi Dangkal Di

Aviva Stevani, et al. Tanah Gambut Dengan Stabilisas Kapur dan Abu Sekam Padi

Tabel 2. Nilai Poisson Tanah

\begin{tabular}{cc}
\hline Jenis Tanah & Rasio Poisson, $\mu_{s}$ \\
\hline Pasir lepas & $0,2-0,4$ \\
Pasir sedang & $0,25-0,40$ \\
Pasir padat & $0,3-0,45$ \\
Pasir berlempung & $0,2-0,4$ \\
Lempung lunak & $0,15-0,25$ \\
Lempung sedang & $0,2-0,5$ \\
\hline
\end{tabular}

(Sumber: Das \& Sobhan, 2014)

Variasi nilai $I_{f}$ terhadap B/L, Df/B dan $\mu_{s}$ dapat dilihat lebih lanjut pada Tabel 3.

Tabel 3. Variasi Nilai $I_{f}$ terhadap B/L, Df/B dan $\mu_{s}$

\begin{tabular}{ccccc}
\hline & & \multicolumn{3}{c}{$B / L$} \\
\cline { 3 - 5 }$\mu_{s}$ & $D f / B$ & 0.2 & 0.5 & 1.0 \\
\hline 0.3 & 0,2 & 0,95 & 0,93 & 0,90 \\
& 0,4 & 0,90 & 0,86 & 0,81 \\
& 0,6 & 0,85 & 0,80 & 0,74 \\
0.4 & 1,0 & 0,78 & 0,71 & 0,65 \\
& 0,2 & 0,97 & 0,96 & 0,93 \\
& 0,4 & 0,93 & 0,89 & 0,85 \\
& 0,6 & 0,89 & 0,84 & 0,78 \\
& 1,0 & 0,82 & 0,75 & 0,69 \\
& 0,2 & 0,99 & 0,98 & 0,96 \\
& 0,4 & 0,95 & 0,93 & 0,89 \\
& 0,6 & 0,92 & 0,87 & 0,82 \\
& 1,0 & 0,85 & 0,79 & 0,72 \\
\hline
\end{tabular}

(Sumber: Das, 2014)

Untuk menentukan nilai Kc dapat menggunakan nilai OCR dengan kurva hubungan antara OCR dengan Kc seperti yang terlampir pada Gambar 2 .

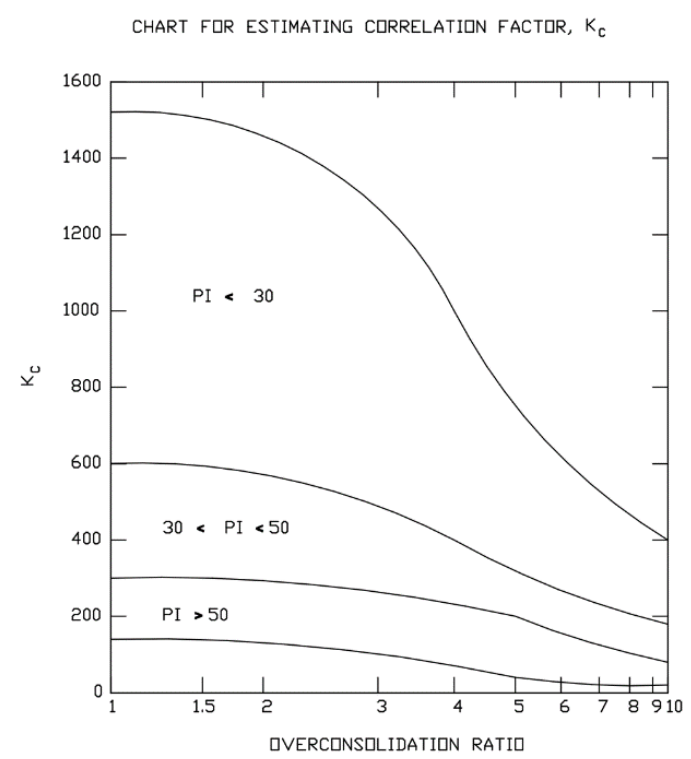

Gambar 2. Kurva Hubungan Indeks Plastisitas, OCR dan Faktor Korelasi untuk Es (Sumber: USACE, 1992) 


\section{Konsolidasi Primer}

Pada penurunan ini, tegangan air pori secara kontinu berpindah ke dalam tegangan efektif sebagai akibat dari keluarnya air pori dari tanah. Saat tanah mengalami penurunan konsolidasi, akan terjadi kompresi yang menyebabkan perubahan nilai void ratio. Besar penurunan konsolidasi primer pada tanah lempung dapat dirumuskan sebagai berikut:

Untuk overconsolidated:

$$
\begin{aligned}
& \sigma_{o}^{\prime}+\Delta \sigma^{\prime} \leq \sigma_{c}^{\prime} \rightarrow S_{c}=\frac{C_{S} H}{1+e_{o}} \log \left(\frac{{\sigma^{\prime}{ }_{o}+\Delta \sigma^{\prime}}_{\sigma_{o}}}{{ }^{\prime}}\right) \\
& {\sigma^{\prime}}_{o}+\Delta \sigma^{\prime}>\sigma^{\prime}{ }_{c} \rightarrow S_{c}=\frac{C_{S} H}{1+e_{o}} \log \frac{{\sigma^{\prime}}_{c}}{\sigma^{\prime}{ }_{o}}+\frac{C_{c} H}{1+e_{o}} \log \left(\frac{\sigma_{{ }^{\prime}}{ }+\Delta \sigma^{\prime}}{\sigma^{\prime}{ }_{o}}\right)
\end{aligned}
$$

Untuk normally consolidated:

$$
S_{c}=\frac{C_{c} H}{1+e_{o}} \log \left(\frac{\sigma^{\prime}{ }_{o}+\Delta \sigma^{\prime}}{\sigma_{o}^{\prime}}\right)
$$

dengan $\mathrm{S}_{c}=$ penurunan primer, $C_{S}=$ indeks pemuaian, $e_{o}=$ angka pori, $\mathrm{H}=$ tebal lapisan tanah, $\Delta \sigma^{\prime}=$ perubahan tekanan, $\sigma^{\prime}{ }_{o}=$ tekanan prakonsolidasi (overconsolidated), $C_{c}=$ indeks kompresibilitas dan $\sigma^{\prime}{ }_{o}=$ tekanan overburden efektif (normally consolidated).

Penentuan nilai indeks kompresi (Cc) dapat menggunakan persamaan-persamaan yang terlampir pada Tabel 4.

Tabel 4. Hubungan Untuk Indeks Kompresi Cc

\begin{tabular}{ll}
\hline Persamaan & Daerah Pemakaian \\
\hline$C_{c}=0,007(L L-7)$ Skempton & Lempung yang terbentuk Kembali (remolded) \\
$C_{c}=0,01 W N$ & Lempung Chicago \\
$C_{c}=1,15\left(e_{o}-0,27\right)$ Nishida & Semua lempung \\
$C_{c}=0,30\left(e_{o}-0,27\right)$ Hough & Tanah kohesif anorganik: lanau, lempung berlanau, \\
& lempung \\
$C_{c}=0,0115 W N$ & Tanah organik, gambut, lanau organik, dan lempung \\
$C_{c}=0,0046(L L-9)$ & Lempung Brazilia \\
$C_{c}=0,75\left(e_{o}-0,5\right)$ & Tanah dengan plastisitas rendah \\
$\left.C_{c}=0,208 e_{o}+0,0083\right)$ & Lempung Chicago \\
$\left.C_{c}=0,1568 e_{o}+0,0107\right)$ & Semua lempung \\
\hline
\end{tabular}
(Sumber: Das, 2014)

Nilai Cs digunakan persamaan:

$$
C_{s}=\frac{1}{4} \text { to } \frac{1}{5} C c
$$

\section{Konsolidasi Sekunder}

Penurunan konsolidasi sekunder adalah penurunan setelah tekanan air pori hilang seluruhnya. Hal ini disebabkan oleh proses konsolidasi akibat penyesuaian yang bersifat plastis dari butir-butir tanah. Konsolidasi sekunder sering dianggap sebagai penurunan konsolidasi yang berlangsung di akhir tahap penurunan konsolidasi primer. Pada tanah organik seperti tanah gambut, konsolidasi sekunder sangat berpengaruh.

$$
\begin{array}{r}
S_{s}=C^{\prime}{ }_{\alpha} H \log \left(\frac{t_{2}}{t_{1}}\right) \\
e_{p}=e_{o}-\Delta e_{\text {primary }} \\
\Delta e=C_{c} \log \left(\frac{\sigma_{o^{\prime}+\Delta \sigma^{\prime}}}{\sigma^{\prime}{ }_{o}}\right) \\
\frac{C^{\prime}{ }_{\alpha}}{C_{c}} \approx 0,075 \pm 0,01
\end{array}
$$




$$
C_{\alpha}^{\prime}=\frac{C_{\alpha}}{1+e_{p}}
$$

dengan $\mathrm{S}_{S}=$ konsolidasi sekunder, $C_{\alpha}=$ indeks pemampatan sekunder, $\mathrm{t}_{1}=$ waktu yang dibutuhkan pada tahap konsolidasi primer, $t_{2}=$ waktu yang dibutuhkan pada tahap konsolidasi sekunder, $\Delta e=$ perubahan angka pori dan $\mathrm{e}_{\mathrm{p}}=$ angka pori di akhir konsolidasi primer.

\section{Laju Penurunan Konsolidasi}

Berikut rumus yang digunakan untuk mencari laju penurunan konsolidasi:

$$
T_{v}=\frac{c_{v} t}{H^{2} d r}
$$

Untuk $\mathrm{U}=0 \%-60 \%$ :

$$
T_{v}=\frac{\pi}{4}\left(\frac{U \%}{100}\right)^{2}
$$

Untuk U > 60\%:

$$
T_{v}=1,781-0,933 \log (100-U \%)
$$

dengan $u_{0}=$ tekanan air pori berlebih inisial, $u_{z}=$ tekanan air pori pada kedalaman $\mathrm{z}, T_{v}=$ faktor waktu dari konsolidasi, $H_{d r}=$ panjang maksimum aliran drainase dan $\mathrm{U}=$ derajat konsolidasi.

\section{METODE PENELITIAN}

Dalam penelitian ini ada beberapa tahapan yang dilakukan anatara lain:

- Tahap awal dari penelitian ini dimulai dengan mengumpukan data dan teori-teori serta parameter tanah yang akan ditinjau dari jurnal-jurnal dan buku-buku yang bersangkutan.

- Langkah berikutnya adalah mengkorelasikan data-data tanah yang ada umtuk mendapatkan parameterparameter yang digunakan dalam analisis perhitungan.

- Langkah berikutnya adalah memodelkan fondasi dangkal yang akan dipakai serta teori/metode apa saja yang akan digunakan dalam analisis perhitungan.

- Menganalisis penurunan tanah yang terjadi akibat beban rumah tinggal beserta fondasi yang digunakan pada tanah gambut asli dan yang sudah distabilisasi.

- Langkah terakhir adalah membandingkan hasil perhitungan pada kedua tanah gambut, apakah dengan stabilisasi, terjadi perubahan penurunan, setelah itu menarik kesimpulan dari data yang didapat.

\section{HASIL DAN PEMBAHASAN}

Pada perhitungan penurunan ini, jenis fondasi yang digunakan adalah fondasi dangkal berbentuk bujur sangkar dengan ukuran $2 \mathrm{~m}$ x $2 \mathrm{~m}$ yang diletakkan pada kedalaman $1 \mathrm{~m}$ dari permukaan tanah. Beban yang diperhitungkan hanya beban vertical sebesar $20,9 \mathrm{kN}$ dan momen sebesar $8,96 \mathrm{kNm}$ yang diambil dari perencanaan rumah tinggal 2 lantai. Perhitungan penurunan yang ditinjau hanya pada ketebalan lapisan gambut saja, yaitu sebesar $6 \mathrm{~m}$. Kedalaman muka air tanah pada elevasi \pm 0.00 pada saat saat banjir. Tanah gambut yang digunakan berasal dari Kalimantan Tengah. Ketebalan gambut yang distabilisasi dimulai dari muka tanah. Berikut terlampir permodelan fondasi dangkal beserta beban yang digunakan untuk perhitungan pada Gambar 3. 


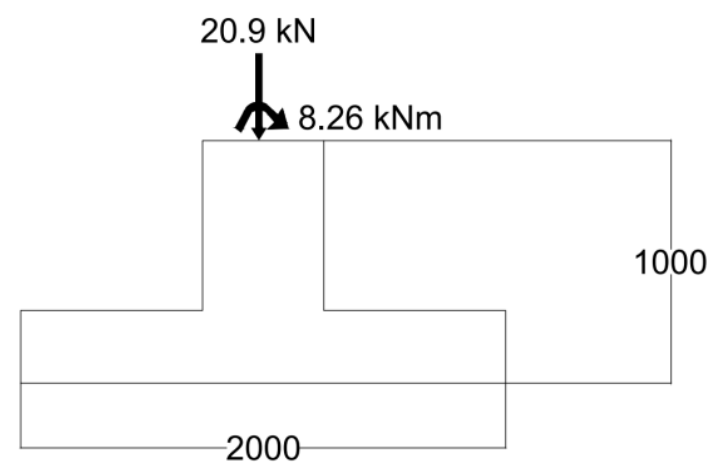

Gambar 3. Permodelan Fondasi Dangkal (Sumber: data primer)

Tanah gambut yang digunakan untuk perhitungan settlement berasal dari Kalimantan Tengah. Berikut terlampir data tanah gambut asli (kondisi awal) yang didapatkan dari uji laboratorium yang terlampir pada Tabel 5.

Tabel 5. Properti Fisik Tanah Gambut Asli yang Ditinjau

\begin{tabular}{cccc}
\hline Parameter & & $\begin{array}{c}\text { Tanah gambut } \\
\text { yang ditinjau }\end{array}$ & $\begin{array}{c}\text { Tanah gambut yang ditinjau oleh } \\
\text { peneliti lainnya }\end{array}$ \\
\hline Specific Gravity $(\mathrm{Gs})$ & - & 1,49 & $1,4-1,7$ \\
Angka Pori & - & 9,7 & $6,89-11,09$ \\
Berat Jenis & $\mathrm{t} / \mathrm{m}^{3}$ & 1,044 & $0,9-1,25$ \\
pH & - & 3,1 & 3,7 \\
Kadar Air & $\%$ & 649,78 & $450-1500$ \\
Kadar Organik & $\%$ & 97,0 & $62,5-98$ \\
Kadar Abu & $\%$ & 3,0 & $2-37,5$ \\
Kadar Serat & $\%$ & 52,1 & $39,5-61,3$ \\
Koef. Permeabilitas & $\mathrm{cm} / \mathrm{min}$ & $6,38 \times 10^{-3}$ & $10^{-3}-10^{-6}$ \\
Kuat Geser & $\mathrm{kPa}$ & 26,85 & - \\
\hline
\end{tabular}

(Sumber: Yulianto dan Mochtar, 2010)

Tanah gambut stabilisasi yang digunakan untuk menghitung penurunan, distabilisasi dengan campuran bahan kimia, yaitu kapur dan abu sekam padi. Kadar kapur sebesar 30\% dan kadar abu sekam padi sebesar 70\%, dimana kadar admixture adalah $10 \%$ dari tanah gambut. Berikut terlampir properti fisik tanah gambut yang ditinjau, terlampir pada Tabel 6.

Tabel 6. Properti Fisik Tanah Gambut Stabilisasi yang Ditinjau

\begin{tabular}{|c|c|c|}
\hline Parameter & & $\begin{array}{c}\text { Tanah gambut yang } \\
\text { distabilisasi }\end{array}$ \\
\hline Specific Gravity (Gs) & - & 2,16 \\
\hline Angka Pori & - & 6,31 \\
\hline Berat Jenis & $\mathrm{t} / \mathrm{m}^{3}$ & 1,120 \\
\hline $\mathrm{pH}$ & - & 6,27 \\
\hline Kadar Air & $\%$ & 270,26 \\
\hline Kadar Organik & $\%$ & 54,97 \\
\hline Kadar Abu & $\%$ & 45,43 \\
\hline Kuat Geser & $\mathrm{kPa}$ & 34,6 \\
\hline
\end{tabular}

(Sumber: Yulianto dan Mochtar, 2010)

Untuk beberapa parameter yang tidak ada dalam data laboratorium, dilakukan korelasi dan menggunakan typical value, berikut rekapitulasi data untuk perhitungan yang terlampir pada Tabel 7. 
Tabel 7. Parameter Tanah Gambut Asli

\begin{tabular}{cccc}
\hline Parameter & Simbol & Unit & $\begin{array}{c}\text { Tanah Gambut Asli } \\
\text { yang ditinjau }\end{array}$ \\
\hline Berat Isi & $\gamma$ & $\mathrm{kN} / \mathrm{m}^{3}$ & 10,44 \\
Indeks plastisitas & $\mathrm{Ip}$ & $\%$ & 65 \\
Kuat geser & $\mathrm{Cu}$ & $\mathrm{kPa}$ & 26,85 \\
Angka pori & $\mathrm{e} 0$ & - & 9,7 \\
Indeks kompresi & $\mathrm{Cc}$ & - & 4,710905 \\
Indeks rekompresi & $\mathrm{Cs}$ & - & 0,942181 \\
Koefisien konsolidasi & $\mathrm{Cv}$ & $\mathrm{m}^{2} / \mathrm{s}$ & 0,0000018 \\
Koefisien kompresi sekunder & $\mathrm{C} \alpha$ & - & 0,2826543 \\
Rasio terkonsolidasi lebih & $\mathrm{OCR}$ & - & 7,8 \\
\hline
\end{tabular}

Berikut data parameter tanah gambut stabilisasi yang digunakan dalam perhitungan terlampir pada Tabel 8.

Tabel 8. Parameter Tanah Gambut Stabilisasi

\begin{tabular}{cccc}
\hline Parameter & Simbol & Unit & $\begin{array}{c}\text { Tanah Gambut Asli } \\
\text { yang ditinjau }\end{array}$ \\
\hline Berat Isi & $\gamma$ & $\mathrm{kN} / \mathrm{m}^{3}$ & 11,2 \\
Indeks plastisitas & $\mathrm{Ip}$ & $\%$ & 52 \\
Kuat geser & $\mathrm{Cu}$ & $\mathrm{kPa}$ & 34,6 \\
Angka pori & $\mathrm{e} 0$ & - & 6,31 \\
Indeks kompresi & $\mathrm{Cc}$ & - & 1,959385 \\
Indeks rekompresi & $\mathrm{Cs}$ & - & 0,391877 \\
Koefisien konsolidasi & $\mathrm{Cv}$ & $\mathrm{m}^{2} / \mathrm{s}$ & 0,00000144 \\
Koefisien kompresi sekunder & $\mathrm{C} \alpha$ & - & 0,00000144 \\
Rasio terkonsolidasi lebih & $\mathrm{OCR}$ & - & 9,5 \\
\hline
\end{tabular}

Contoh perhitungan penurunan elastis pada tanah gambut asli pada lapisan gambut setebal 6m sebagai berikut:

$$
\begin{aligned}
& \Delta \sigma=\frac{V}{A}+\frac{M_{y} X}{I_{y}}+\frac{M_{x} Y}{I_{x}} \\
& \Delta \sigma=\frac{20,9 k N}{4 m^{2}}+\frac{8,96 k N m \times 1 \mathrm{~m}}{1,33333 \mathrm{~m}^{4}}+\frac{8,96 \mathrm{kNm} \times 1 \mathrm{~m}}{1,33333 \mathrm{~m}^{4}} \\
& =17,615 \mathrm{kN} / \mathrm{m}^{2} \\
& \alpha=4 \\
& \mathrm{~m}^{\prime}=\frac{\mathrm{L}}{\mathrm{B}}=\frac{2 \mathrm{~m}}{2 \mathrm{~m}}=1 \\
& \mathrm{n}^{\prime}=\frac{\mathrm{H}}{\left(\frac{\mathrm{B}}{2}\right)}=\frac{5 \mathrm{~m}}{\left(\frac{2 \mathrm{~m}}{2}\right)}=5 \\
& \mathrm{~B}^{\prime}=\frac{\mathrm{B}}{2}=\frac{2 \mathrm{~m}}{2}=1 \mathrm{~m} \\
& \mu_{\mathrm{s}}=0,35 \\
& \mathrm{I}_{\mathrm{f}}=0,7825 \\
& \mathrm{E}_{\mathrm{s}}=\mathrm{K}_{\mathrm{c}} \times \mathrm{C}_{\mathrm{u}}
\end{aligned}
$$


Dari grafik, diperoleh $K_{c} \approx 73$

$$
\begin{aligned}
\mathrm{E}_{\mathrm{s}} & =73 \times 26,85 \mathrm{kN} / \mathrm{m}^{2} \\
& =1960,05 \mathrm{kN} / \mathrm{m}^{2} \\
\mathrm{~A}_{0} & =\mathrm{m}^{\prime} \ln \frac{\left(1+\sqrt{\mathrm{m}^{\prime 2}+1}\right) \sqrt{\mathrm{m}^{\prime 2}+\mathrm{n}^{\prime 2}}}{\mathrm{~m}^{\prime}\left(1+\sqrt{\mathrm{m}^{\prime 2}+\mathrm{n}^{\prime 2}+1}\right)} \\
& =1 \ln \frac{\left(1+\sqrt{1^{2}+1}\right) \sqrt{1^{2}+5^{2}}}{1\left(1+\sqrt{1^{2}+5^{2}+1}\right)} \\
& =0,68649
\end{aligned}
$$

\begin{tabular}{|c|c|c|c|c|c|c|}
\hline & $\begin{array}{c}\text { Tanah } \\
\text { Gambut asli }\end{array}$ & $\begin{array}{c}\text { Tanah } \\
\text { Gambut } \\
\text { Stabilisasi } 2 \\
\mathrm{~m}\end{array}$ & $\begin{array}{c}\text { Tanah } \\
\text { Gambut } \\
\text { Stabilisasi } 3 \\
\text { m }\end{array}$ & $\begin{array}{c}\text { Tanah } \\
\text { Gambut } \\
\text { Stabilisasi } 4 \\
\text { m }\end{array}$ & $\begin{array}{c}\text { Tanah } \\
\text { Gambut } \\
\text { Stabilisasi } 5 \\
\text { m }\end{array}$ & $\begin{array}{c}\text { Tanah } \\
\text { Gambut } \\
\text { Stabilisasi } 6 \\
\text { m }\end{array}$ \\
\hline $\begin{array}{l}\text { Penurunan } \\
\text { Elastis }\end{array}$ & $1.114 \mathrm{~cm}$ & $0,7470 \mathrm{~cm}$ & $0,7382 \mathrm{~cm}$ & $0,7458 \mathrm{~cm}$ & $0,7632 \mathrm{~cm}$ & $0,7888 \mathrm{~cm}$ \\
\hline
\end{tabular}

$$
\begin{aligned}
\mathrm{A}_{1} & =\ln \frac{\left(\mathrm{m}^{\prime}+\sqrt{\mathrm{m}^{\prime 2}+1}\right) \sqrt{1+\mathrm{n}^{\prime 2}}}{\mathrm{~m}^{\prime}+\sqrt{\mathrm{m}^{\prime 2}+\mathrm{n}^{\prime 2}+1}} \\
& =\ln \frac{\left(1+\sqrt{1^{2}+1}\right) \sqrt{1+5^{2}}}{1+\sqrt{1^{2}+5^{2}+1}} \\
& =0,68649 \\
\mathrm{~A}_{2} & =\frac{\mathrm{m}}{\mathrm{n}^{\prime} \sqrt{\mathrm{m}^{\prime 2}+\mathrm{n}^{\prime 2}+1}} \\
& =\frac{1}{5 \sqrt{1^{2}+5^{2}+1}} \\
& =0,03849 \\
\mathrm{~F}_{2} & =\frac{\mathrm{n}^{\prime}}{2 \pi} \tan ^{-1} \mathrm{~A}_{2} \\
& =\frac{5}{2 \pi} \tan ^{-1} 0,03849 \\
& =0,03061 \\
\mathrm{~F}_{1} & =\frac{1}{\pi}\left(\mathrm{A}_{0}+\mathrm{A}_{1}\right) \\
& =\frac{1}{\pi}(0,68649+0,68649) \\
& =0,43704 \\
\mathrm{I}_{\mathrm{s}} & =\mathrm{F}_{1}+\frac{1-2 \mu_{\mathrm{s}}}{1-\mu_{\mathrm{s}}} \mathrm{F}_{2} \\
& =0,43704+\frac{1-2(0,35)}{1-0,35} 0,03061 \\
& =0,45116 \\
\mathrm{~S}_{\mathrm{e}} & =\Delta \sigma\left(\alpha \mathrm{B}^{\prime}\right) \frac{1-\mu_{\mathrm{s}}}{\mathrm{E}_{\mathrm{s}}} \mathrm{I}_{\mathrm{s}} \mathrm{I}_{\mathrm{f}} \\
& =17,615 \mathrm{kN} / \mathrm{m}^{2}(4 \times 1 \mathrm{~m}) \frac{1-0,35^{2}}{1960,05 \frac{k N}{m^{2}}} 0,45116 \times 0,7825 \\
& =0,01114 \mathrm{~m}
\end{aligned}
$$

Hasil penurunan elastis pada tanah gambut asli dan tanah gambut yang telah distabilisasi dengan ketebalan yang berbeda dapat dilihat pada Tabel 9 .

Tabel 9. Penurunan Elastis Pada Tanah Gambut Asli dan Stabilisasi Dengan Ketebalan yang Berbeda 
Analisis Perbandingan Penurunan Fondasi Dangkal Di

Padi

Perhitungan konsolidasi primer pada analisis kali ini diasumsikan tanah sudah mencapai $\mathrm{U}=90 \%$. Kedalaman konsolidasi yang ditinjau yaitu $6 \mathrm{~m}$ dari permukaan tanah. Berikut merupakan contoh perhitungannya.

- Lapisan 1 (Gambut Ketebalan $1 \mathrm{~m}$ )

$\Delta \sigma^{\prime}=17,615 \mathrm{kN} / \mathrm{m}^{2}$

$\sigma^{\prime}{ }_{\mathrm{o}}=\gamma \times \frac{\mathrm{H}}{2}=(10,44-9,81) \times \frac{1}{2}=0,945 \mathrm{kN} / \mathrm{m}^{2}$

$\sigma^{\prime}{ }_{\mathrm{c}}=$ OCR $\times \sigma_{\mathrm{o}}^{\prime}=7,8 \times 0,945=7,371 \mathrm{kN} / \mathrm{m}^{2}$

Cek $\sigma^{\prime}{ }_{\mathrm{o}}+\Delta \sigma^{\prime}>\sigma_{\mathrm{c}}^{\prime}$

$\sigma^{\prime}{ }_{\mathrm{o}}+\Delta \sigma^{\prime}=0,945+17,615=18,56 \mathrm{kN} / \mathrm{m}^{2}>\sigma^{\prime}{ }_{\mathrm{c}}(\mathrm{OC})$

$S_{e}=\frac{C_{S} H}{1+e_{o}} \log \frac{\sigma^{\prime} C}{\sigma_{\prime}^{\prime}}+\frac{C_{C} H}{1+e_{o}} \log \left(\frac{\sigma^{\prime} o_{o}+\Delta \sigma \prime}{\sigma^{\prime}{ }_{o}}\right)$

$S_{e}=\frac{0,942181 \times 1}{1+9,7} \log \frac{7,371}{0,945}+\frac{4,710905 \times 1}{1+9,7} \log \left(\frac{18,56}{0,945}\right)=0,64788816 m$

Untuk laju penurunan konsolidasi primer dengan $U=90 \%$ :

$\mathrm{T}_{\mathrm{v}}=1,781-0,933 \log (100-\mathrm{U} \%)=1,781-0,933 \log (100-90)$

$=0,848$

$\mathrm{t}=\frac{\mathrm{T}_{\mathrm{v}} \mathrm{H}^{2}}{\mathrm{c}_{\mathrm{v}}}=\frac{0,848 \times 1^{2}}{0,0000018}=470944,4 \mathrm{~s}=5,45075$ hari $=0,014934$ tahun

- Lapisan 2 (Gambut Ketebalan $4 \mathrm{~m}$ )

$\Delta \sigma^{\prime}=5,8933 \mathrm{kN} / \mathrm{m}^{2}$

${\sigma^{\prime}}_{o}=\gamma \times \frac{H}{2}+1,26 \frac{\mathrm{kN}}{\mathrm{m}^{2}}=(10,44-9,81) \times \frac{4}{2}+1,26 \mathrm{kN} / \mathrm{m}^{2}=2,52 \mathrm{kN} / \mathrm{m}^{2}$

$\sigma^{\prime}{ }_{\mathrm{c}}=$ OCR $\times \sigma^{\prime}{ }_{\mathrm{o}}=7,8 \times 2,52=19,656 \mathrm{kN} / \mathrm{m}^{2}$

$\operatorname{Cek} \sigma_{\mathrm{o}}^{\prime}+\Delta \sigma^{\prime} \leq \sigma_{\mathrm{c}}^{\prime}$

$\sigma^{\prime}{ }_{\mathrm{o}}+\Delta \sigma^{\prime}=2,52+5,8933=8,413333 \mathrm{kN} / \mathrm{m}^{2} \leq \sigma^{\prime}{ }_{\mathrm{c}}(\mathrm{OC})$

$\mathrm{S}_{\mathrm{e}}=\frac{\mathrm{C}_{\mathrm{S}} \mathrm{H}}{1+\mathrm{e}_{\mathrm{o}}} \log \left(\frac{\sigma_{\prime_{\mathrm{o}}}+\Delta \sigma \prime}{\sigma \prime_{\mathrm{o}}}\right)$

$S_{e}=\frac{0,9422 \times 4}{1+9,7} \log \left(\frac{8,413333}{2,52}\right)=0,184409 \mathrm{~m}$

Untuk laju penurunan konsolidasi primer dengan $U=90 \%$ :

$$
\begin{aligned}
\mathrm{T}_{\mathrm{v}} & =1,781-0,933 \log (100-\mathrm{U} \%) \\
& =1,781-0,933 \log (100-90) \\
& =0,848 \\
\mathrm{t} & =\frac{\mathrm{T}_{\mathrm{v}} \mathrm{H}^{2}}{\mathrm{c}_{\mathrm{v}}} \\
& =\frac{0,848 \times 4^{2}}{0,0000018}=7535111 \mathrm{~s}=87,2120 \text { hari }=0,238937 \text { tahun }
\end{aligned}
$$

TOTAL PENURUNAN =0,647888 $\mathrm{m}+0,184409 \mathrm{~m}=0,83229 \mathrm{~m}=83,2298 \mathrm{~cm}$

Hasil perhitungan konsolidasi primer pada tanah gambut asli dan tanah gambut yang telah distabilisasi dengan keteblaan yang berbeda dapat dilihat pada Tabel 10 . 
Tabel 10. Konsolidasi Primer Pada Tanah GambutAsli dan Stabilisasi Dengan Ketebalan yang Berbeda

\begin{tabular}{|c|c|c|c|c|c|c|}
\hline & $\begin{array}{c}\text { Tanah } \\
\text { Gambut Asli }\end{array}$ & $\begin{array}{c}\text { Tanah } \\
\text { Gambut } \\
\text { Stabilisasi } 2 \\
\text { m }\end{array}$ & $\begin{array}{c}\text { Tanah } \\
\text { Gambut } \\
\text { Stabilisasi } 3 \\
\text { m }\end{array}$ & $\begin{array}{c}\text { Tanah } \\
\text { Gambut } \\
\text { Stabilisasi } 4 \\
\text { m }\end{array}$ & $\begin{array}{c}\text { Tanah } \\
\text { Gambut } \\
\text { Stabilisasi } 5 \\
\text { m }\end{array}$ & $\begin{array}{c}\text { Tanah } \\
\text { Gambut } \\
\text { Stabilisasi } 6 \\
\text { m }\end{array}$ \\
\hline $\begin{array}{l}\text { Konsolidasi } \\
\text { Primer }\end{array}$ & $83.2298 \mathrm{~cm}$ & $18.9904 \mathrm{~cm}$ & $14.2862 \mathrm{~cm}$ & $14.3460 \mathrm{~cm}$ & $15.9025 \mathrm{~cm}$ & $19.2460 \mathrm{~cm}$ \\
\hline
\end{tabular}

Perhitungan konsolidasi sekunder pada analisis ini, diasumsikan bahwa konsolidasi sekunder berakhir pada jangka waktu 30 tahun. Berikut contoh perhitungan konsolidasi sekunder.

- Lapisan 1 (Gambut Ketebalan $1 \mathrm{~m}$ )

$$
\begin{gathered}
\Delta e=C_{c} \log \left(\frac{\sigma_{o}+\Delta \sigma^{\prime}}{\sigma_{o}^{\prime}}\right)=4,710905 \log \left(\frac{18,56}{0,945}\right)=6,091889 \\
e_{p}=e_{o}-\Delta e_{\text {primary }}=9,7-6,091889=3.608111 \\
S_{S}=\frac{C_{\alpha} H}{1+e_{p}} \log \left(\frac{t_{2}}{t_{1}}\right)=\frac{0,282654 \times 1}{1+3,608111} \log \left(\frac{29,98507}{0,014934}\right)=0,127111 \mathrm{~m}
\end{gathered}
$$

- Lapisan 2 (Gambut Ketebalan $4 \mathrm{~m}$ )

$\Delta e=C_{c} \log \left(\frac{\sigma_{o}^{\prime}+\Delta \sigma^{\prime}}{\sigma_{\prime}^{\prime}}\right)=4,710905 \log \left(\frac{8,413333}{2,56}\right)=2,46648$

$e_{p}=e_{o}-\Delta e_{\text {primary }}=9,7-2,46648=7,23352$

$S_{S}=\frac{C_{\alpha} H}{1+e_{p}} \log \left(\frac{t_{2}}{t_{1}}\right)=\frac{0,282654 \times 1}{1+7,23352} \log \left(\frac{29,7611}{0,23894}\right)=0,287733 \mathrm{~m}$

$$
\text { TOTAL PENURUNAN }=0,127111 \mathrm{~m}+0,287733 \mathrm{~m}=0,41844 \mathrm{~m}
$$

\begin{tabular}{|c|c|c|c|c|c|c|}
\hline & $\begin{array}{c}\text { Tanah } \\
\text { Gambut Asli }\end{array}$ & $\begin{array}{c}\text { Tanah } \\
\text { Gambut } \\
\text { Stabilisasi } 2 \\
\text { m }\end{array}$ & $\begin{array}{c}\text { Tanah } \\
\text { Gambut } \\
\text { Stabilisasi } 3 \\
\text { m }\end{array}$ & $\begin{array}{c}\text { Tanah } \\
\text { Gambut } \\
\text { Stabilisasi } 4 \\
\text { m }\end{array}$ & $\begin{array}{c}\text { Tanah } \\
\text { Gambut } \\
\text { Stabilisasi } 5 \\
\text { m }\end{array}$ & $\begin{array}{c}\text { Tanah } \\
\text { Gambut } \\
\text { Stabilisasi } 6 \\
\text { m }\end{array}$ \\
\hline $\begin{array}{l}\text { Konsolidasi } \\
\text { Sekunder }\end{array}$ & $33,7213 \mathrm{~cm}$ & $25,4709 \mathrm{~cm}$ & $28,1175 \mathrm{~cm}$ & $26,9993 \mathrm{~cm}$ & $17,9368 \mathrm{~cm}$ & $33,7213 \mathrm{~cm}$ \\
\hline
\end{tabular}

Hasil perhitungan konsolidasi sekunder pada tanah gambut asli dan tanah gambut yang telah distabilisasi dengan keteblaan yang berbeda dapat dilihat pada Tabel 11

Tabel 11. Konsolidasi Sekunder Pada Tanah Gambut Asli dan Stabilisasi Dengan Ketebalan yang Berbeda

Berikut summary hasil perhitungan penurunan yang telah dilakukan pada tanah gambut asli dan pada tanah gambut yang telah distabilisasi, terlampir pada Tabel 12.

Tabel 12. Sumary Penurunan

\begin{tabular}{ccccccc}
\hline & $\begin{array}{c}\text { Tanah } \\
\text { Gambut } \\
\text { Asli }\end{array}$ & $\begin{array}{c}\text { Tanah } \\
\text { Gambut } \\
\text { Stabilisasi 2 } \\
\mathrm{m}\end{array}$ & $\begin{array}{c}\text { Tanah } \\
\text { Gambut } \\
\text { Stabilisasi 3 } \\
\mathrm{m}\end{array}$ & $\begin{array}{c}\text { Tanah } \\
\text { Gambut } \\
\text { Stabilisasi 4 } \\
\mathrm{m}\end{array}$ & $\begin{array}{c}\text { Tanah } \\
\text { Gambut } \\
\text { Stabilisasi 5 } \\
\mathrm{m}\end{array}$ & $\begin{array}{c}\text { Tanah } \\
\text { Gambut } \\
\text { Stabilisasi 6 } \\
\mathrm{m}\end{array}$ \\
\hline Se $(\mathrm{cm})$ & 1,1136 & 0,7470 & 0,7382 & 0,7458 & 0,7633 & 0,7886 \\
Sc $(\mathrm{cm})$ & 83,2298 & 18,9904 & 14,2862 & 14,3460 & 15,9025 & 19,2460 \\
Ss $(\mathrm{cm})$ & 41,4844 & 33,7213 & 25,4709 & 28,1175 & 26,9993 & 17,9368 \\
Total & 125,828 & 53,4587 & 40,4953 & 43,2094 & 43,6651 & 37,9714 \\
\hline
\end{tabular}

Berikut summary hasil perhitungan penurunan (dalam persentase) yang telah dilakukan pada tanah gambut asli dan pada tanah gambut yang telah distabilisasi, terlampir pada Tabel 13 . 
Tabel 13. Summary Penurunan Dalam Persentase

\begin{tabular}{ccccccc}
\hline & $\begin{array}{c}\text { Tanah } \\
\text { Gambut } \\
\text { Asli }\end{array}$ & $\begin{array}{c}\text { Tanah } \\
\text { Gambut } \\
\text { Stabilisasi 2 } \\
\mathrm{m}\end{array}$ & $\begin{array}{c}\text { Tanah } \\
\text { Gambut } \\
\text { Stabilisasi 3 } \\
\mathrm{m}\end{array}$ & $\begin{array}{c}\text { Tanah } \\
\text { Gambut } \\
\text { Stabilisasi 4 } \\
\mathrm{m}\end{array}$ & $\begin{array}{c}\text { Tanah } \\
\text { Gambut } \\
\text { Stabilisasi 5 } \\
\mathrm{m}\end{array}$ & $\begin{array}{c}\text { Tanah } \\
\text { Gambut } \\
\text { Stabilisasi 6 } \\
\mathrm{m}\end{array}$ \\
\hline Se (\%) & 3,9279 & 2,9292 & 3,1206 & 3,1896 & 3,6457 & 5,2967 \\
Sc (\%) & 66,1456 & 35,5396 & 35,2787 & 33,2011 & 36,4192 & 50,6855 \\
Ss (\%) & 32,9691 & 63,0792 & 62,8984 & 65,0726 & 61,8327 & 47,2377 \\
\hline
\end{tabular}

Berikut merupakan persentase perbedaan total penurunan pada tanah gambut asli dan pada tanah gambut yang telah distabilisasi, terlampir pada Tabel 14.

Tabel 14. Persentase Perbedaan Penurunan Total Tanah Gambut Stabilisasi Terhadap Tanah Gambut Asli

\begin{tabular}{cccccc}
\hline & Tanah & Tanah & Tanah & Tanah & Tanah \\
& Gambut & Gambut & Gambut & Gambut \\
& $\begin{array}{c}\text { Stabilisasi 2 } \\
\mathrm{m}\end{array}$ & $\begin{array}{c}\text { Stabilisasi 3 } \\
\mathrm{m}\end{array}$ & $\begin{array}{c}\text { Stabilisasi 4 } \\
\mathrm{m}\end{array}$ & $\begin{array}{c}\text { Stabilisasi 5 } \\
\mathrm{m}\end{array}$ & $\begin{array}{c}\text { Stabilisasi 6 } \\
\mathrm{m}\end{array}$ \\
\hline $\begin{array}{c}\text { Tanah Gambut } \\
\text { Asli (\%) }\end{array}$ & 57,5145 & 67,8169 & 65,6599 & 65,2978 & 69,8228 \\
\hline
\end{tabular}

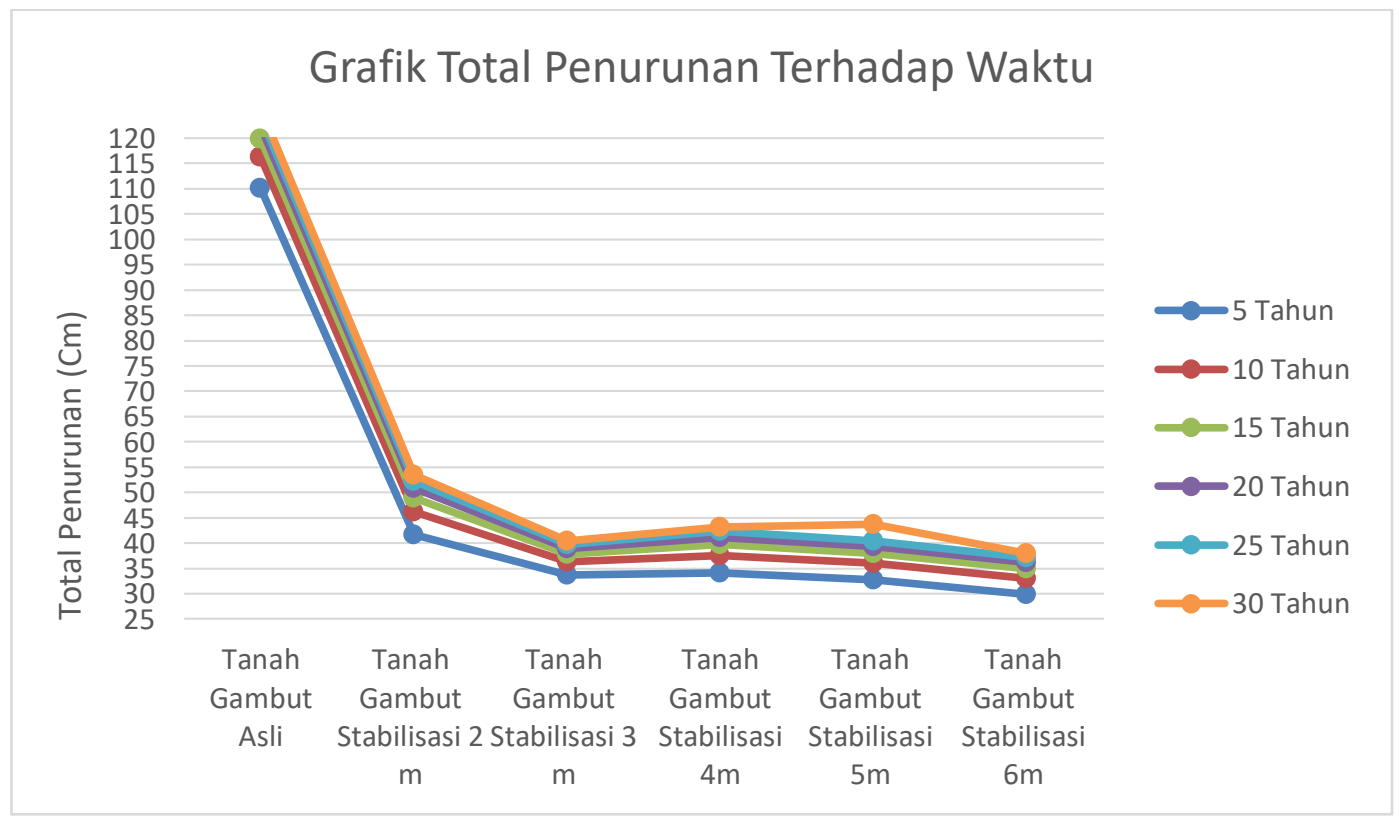

Gambar 4. Grafik Total Penurunan Terhadap Waktu (data primer)

\section{KESIMPULAN DAN SARAN}

Berdasarkan hasil analisis yang telah dilakukan, maka dapat disimpulkan beberapa hal sebagai berikut:

- Setelah distabilisasi dengan kapur dan abu sekam padi, tanah gambut mengalami perbaikan yang ditandai dengan perubahan parameter fisik tanah gambut, seperti nilai specific gravity yang berubah dari 1,49 menjadi 2,16, kadar air yang berkurang dari $649,78 \%$ menjadi $270,26 \%$, angka pori yang mengecil dari 9.7 menjadi 6.31, kadar $\mathrm{pH}$ gambut yang asam $(\mathrm{pH}=3,1)$ berubah menjadi 6,27, kadar organik gambut yang berkurang dari $97 \%$ menjadi $54,97 \%$, serta nilai kuat geser tanah yang meningkat dari $26,85 \mathrm{kPa}$ menjadi 34,6 kPa.

- Dari hasil perhitungan penurunan elastis pada tanah gambut sesuai dengan tabel 12, dapat dilihat bahwa penurunan tanah gambut setelah distabilisasi lebih kecil dibandingkan dengan tanah gambut asli. 
- $\quad$ Nilai Cc dan Cs tanah gambut yang cukup besar menghasilkan nilai penurunan konsolidasi primer dan sekunder yang besar jika dibandingkan dengan penurunan elastis yang dialami seperti yang tertera pada tabel 12.

- Berdasaekan grafik waktu terhadap penurunan, semakin lama waktu penurunan, makin besar total penurunan yang akan terjadi.

Berdasarkan kesimpulan diatas, maka dapat disarankan beberapa hal sebagai berikut:

- Untuk pengambilan parameter rencana tanah, khususnya tanah gambut, disarankan lebih baik untuk menggunakan parameter berdasarkan hasil uji laboratorium, dikarenakan masih sangat sedikit korelasi dan typical value yang dapat digunakan di tanah gambut.

- Pemakaian fondasi dangkal di lahan gambut kurang disarankan jika dilihat dari penurunan yang terjadi, dimana konsolidasi sekunder (penurunan jangka panjang) mengambil peranan penting, serta akan menghasilkan harga yang cukup mahal apabila menggunakan fondasi dangkal, dikarenakan harus memperbaiki tanahnya terlebih dahulu.

\section{DAFTAR PUSTAKA}

Agus, F. and Subiksa I.G.M. Lahan Gambut : Potensi untuk Pertanian dan Aspek Lingkungan. Bogor: Balai Penelitian Tanah, 2008.

Andriesse, J.P. "Nature and Management of Tropical Peat Soils." Soil Resources, Management and Conservation Cervice. FAO Land and Water Development Division. FAO, Rome (1988).

ASTM. "Standard Classification of Peat Samples by Laboratory Testing." Annu. Book ASTM Stand., 4 . D442792. 1995. 628.

Das, Braja M. dan Khaled Sobhan. Principles of Geotechnical Engineering, SI Edition. 8th. Stamford: Cengage Learning, 2014.

Hardiyatmo, H.C. Mekanika Tanah 1. Yogyakarta: Gadjah Mada University Press, 2002.

Hardiyatmo, H.C. Mekanika Tanah 1 . Jakarta : Gramedia Pustaka Umum , 1992. Stabilisasi Tanah Untuk Perkerasan Jalan. Yogyakarta : Gadjah Mada University Press, 2010 .

Mochtar, Noor Endah, Faisal Estu Yulianto and Trihanyndo Rendy S. "Pengaruh Usia Stabilisasi pada Tanah Gambut Berserat yang Distabilisasi dengan Campuran CaCO3 dan Pozolan." Jurmal Teknik Sipil, Jurnal Teoretis dan Terapang Bidang Rekayasa Sipil 21 (2014): 57-64.

Muroby, V. (2020). Kajian Tanah Gambut dan Pelaksanaan Konstruksi di Kalimantan Barat.

Mutalib, et al. "Characterization Distribution adn Utilization of Peat in Malaysia." International Symposium on Tropical Peatland. Kuching, Serawak, Malaysia, 1991.

N.L., Nurida, A. Mulyani and F. Agus. Pengelolaan Lahan Gambut Berkelanjutan. Bogor: Balai Penelitian Tanah, 2011.

Noor, Muhammad, Masganti and Fahmuddin Agus. "Pembentukan dan Karakteristik Gambut Tropika Indonesia ." Lahan Gambut Indonesia . 2014.

Nugroho, K. and B. Widodo. "The Effect of Dry-Wet Condition to Peat Sooil Physical Characteristic of Different Degree of Decomposition." Jakarta Symposium Proceeding on Peatlands for people: Natural Resources Functions and Sustainable Management . 2001. 94-102.

Salampak. "Peningkatan Produktivitas Tanah Gambut yang Disawahkan dengan Pemberian Bahan Amelioran Tanah Mineral Berkadar Besi Tinggi ." Disertasi Program Pasca Sarjana, Institut Pertanian Bogor (1999).

Suhardjo, H. and I P.G Widjaja-Adhi. "Chemical Charcteristic of the Upper $30 \mathrm{cms}$ of Peat Soils From Riau." ATA 106. Bull 3 (1976): 74-92.

T-06-2004-B, Pd. Perencanaan Konstruksi Timbunan Jalan Di Atas Tanah Gambut Dengan Metode Prapembebanan. 2004.

USACE. "Bearing Capacity of Soils." Engineering and Design. 1992.

Wibowo, A. "Peran Lahan Gambut Dalam Perubahan Iklim Global." Jurnal Tekno Hutan Tanaman 2 (2009): 1926.

Yulianto, F.E. and Mochtar, N.E. "Mixing of Rice Husk Ash (RHA) and Lime For Peat Stabilization." Proceedings of the First Makassar International Conference on Civil Engineering (MICCE2010). March 9 102010. 
Analisis Perbandingan Penurunan Fondasi Dangkal Di

Aviva Stevani, et al.

Tanah Gambut Dengan Stabilisas Kapur dan Abu Sekam

Padi 